\title{
Sistem Diagnosa Penyakit Pada Tanaman Cabai Merah Dengan Metode Backward Chaining (Studi Kasus: Petani Cabai Merah Desa Grobongan Kabupaten Madiun)
}

\author{
Ade Eka Novita Pratiwi \\ Fakultas MIPA, Program Studi D3 Teknik Informatika \\ Universitas Sebelas Maret \\ Email: adeekanovitap@student.uns.ac.id
}

\section{Info Artikel}

\section{Kata Kunci :}

sistem pakar, cabai merah, backward chaining, depth first search

\section{Keywords :} expert system, red chili, backward chaining, depth first search

\section{Tanggal Artikel}

Dikirim : 2 Oktober 2018

Direvisi : 25 Oktober 2018

Diterima : 5 November 2018

\section{Abstrak}

Tanaman cabai merah merupakan salah satu tanaman hortikultura yang memiliki banyak jenis penyakit dan sangat mudah menular terhadap tanaman lain jika tidak segera diketahui gejalanya. Dalam mendiagnosis penyakit tanaman cabai, para petani masih menggunakan cara yang sederhana dengan mengamati gejala-gejala yang ada pada tanaman cabai sehingga memerlukan waktu untuk mengenali jenis penyakit cabai. Penelitian sistem pakar diagnosa penyakit tanaman cabai merah ini bertujuan untuk merancang dan membangun suatu sistem untuk mediagnosa penyakit tanaman cabai merah. Model inferensi yang digunakan dalam pembuatan sistem pakar ini adalah penalaran mundur (Backward Chaining) sedangkan teknik pencarian menggunakan Depth First Search. Penentuan diagnosa dalam sistem pakar ini dilakukan melalui proses konsultasi antara sistem dan pemakai. Diharapkan dalam pembuatan sistem pakar dengan menggunakan metode Backward Chaining dalam penelitian ini dapat membantu petani dalam melakukan diagnosa awal terhadap suatu penyakit tanaman cabai dan memberikan solusi untuk mengatasi penyakit tanaman cabai tersebut. Hasil dari pembuatan Sistem Pakar ini mampu membuktikan kebenaran suatu penyakit cabai dan memberi solusi dalam menangani penyakit cabai tersebut.

\begin{abstract}
Abstarct
Red chili plants are one of the horticulture plants that have many types of diseases and are very easily transmitted to other plants if symptoms are not immediately known. In diagnosing chili plant disease, farmers still use a simple method by observing the symptoms that occur in chili plants so that it takes time to recognize the type of chili disease. The research on expert systems for diagnosing red pepper plants aims to design and build a system for the diagnosis of red pepper plants. The inference model used in making this expert system is backward chaining while the search technique uses the Depth First Search. Determining diagnoses in this expert system is carried out through a consultation process between the system and the user. It is hoped that in making an expert system using the Backward Chaining method in this study can help farmers to make an initial diagnosis of a chili plant disease and provide a solution to overcome the chili plant disease. The results of making this Expert System are able to prove the truth of a chili disease and provide a solution in dealing with the chili disease.
\end{abstract}




\section{PENDAHULUAN}

Tanaman cabai merah merupakan jenis buah dan tumbuhan dalam anggota genus Capsicum atau dalam bahasa latin dikenal dengan Capsicum annum L. ini masuk dalam komoditas sayuran yang banyak diminati masyarakat Indonesia. Tanaman cabai merah menjadi salah satu bahan yang sering digunakan oleh masayarakat untuk dijadikan bumbu pada masakan tradisional Indonesia sehingga tidak mengherankan bahwa populasi tanaman cabai khususnya cahai merah sangat mudah dijumpai di pasaran dalam skala yang besar.

Secara geografis Desa Grobongan terletak di Kecamatan Jiwan Kabupaten Madiun, Provinsi Jawa Tengah. Petani di Desa Grobongan memanfaatkan lahan pertanian untuk menanam jenis tanaman hortikultura salah satunya adalah tanaman cabai merah. Sebelumnya dalam mendiagnosa penyakit tanaman cabai merah para petani biasanya mengamati melalui gejala-gejala yang nampak pada tanaman.

Perawatan pada tanaman cabai harus dilakukan dengan sangat ekstra dikarenakan tanaman cabai merah adalah salah satu tanaman yang rentan terhadap penyakit. Jika penyakit pada tanaman cabai tidak cepat diketahui, maka penanganannya akan terlambat sehingga akan mengakibatkan tanaman tersebut tidak dapat berkembang, berhenti berproduksi bahkan tanaman cabai tersebut dapat mati. Hal ini dapat menyebabkan kerugian yang besar bagi para petani cabai. Oleh karena itu dibutuhkan suatu cara yang efektif untuk membantu petani cabai dalam memprediksi penyakit pada tanaman cabai sehingga dapat dilakukan penanganan yang tepat sesuai dengan ciri-ciri yang terdapat pada tanaman tersebut. Cabai merah mampu tumbuh di masa bercocok tanam pada musim hujan (rendengan) maupun masa peralihan dari musim kemarau ke musim penghujan (labuhan), itulah sebabnya cabai dapat

Ditemukan kapan pun di pasar atau di swalayan. Hal inilah yang mendorong perancangan sistem pakar untuk mendiagnosa penyakit pada tanaman cabai merah besar, dengan tujuan untuk memudahkan penanggulangan penyakit pada tanaman cabai merah dengan menggunakan sebuah aplikasi sistem pakar.

Penelitian tentang sistem diagnosa atau sering disebut sistem pakar sudah banyak dilakukan antara lain menurut [1] mengemukakan bahwa perancangan dan pembangunan sistem pakar untuk kerusakan komputer dengan metode backward chaining menitikberatkan untuk mengetahui kerusakan komputer khususnya CPU (Control Processing Unit). Dalam penelitian, mereka membuat beberapa fitur dalam pembuatan sistem pakar kerusakan komputer yaitu halaman index user yang akan diarahkan ke halaman pilihan kerusakan, halaman form diagnosis kerusakan yang akan diarahkan ke form hasil diagnosis dimana terdapat button untuk menuju form penanganan, halaman login admin yang akan diarahkan ke halaman input kerusakan, halaman input solusi, dan halaman input pengetahuan.

Penelitian oleh [2] mengemukakan sistem pakar menawarkan hasil yang spesifik untuk dimanfaatkan karena sistem pakar berfungsi secara konsisten dengan menawarkan solusi dan nasihat seperti seorang pakar manusia termasuk dalam pemecahan masalah penyakit kusta. Sayangnya, ruang lingkup penelitian dipersempit pembahasanya dengan studi kasus di UPT Puskesmas Talango. Pembuatan sistem pakar dengan metode backward chaining dilakukan dengan mengumpulkan basis data, menggolongkan gejala-gejala penyakit kusta, maka akan menghasilkan tabel keputusan. Fitur-fitur yang disediakan yaitu halaman index user dengan menu profil, halaman informasi penyakit kusta, halaman daftar penyakit, halaman konsultasi, halaman petunjuk, halaman login admin; halaman konsultasi akan diarahkan ke halaman input data pasien, halaman pilih jenis penyakit, halaman pertanyaan; halaman pertanyaan akan diarahkan ke halaman hasil diagnosa; halaman login admin akan diarahkan ke halaman input data penyakit, form laporan data penyakit, dan form laporan data gejala.

Menurut [3] mengemukakan manusia bisa menyelesaikan masalah karena manusia mempunyai pengetahuan dan pengalaman agar komputer dapat melakukan tindakan seperti dan sebaik manusia, maka komputer dibekali pengetahuan untuk menalar dengan metode backward chaining. Pendekatan goal-driven, dimulai dari harapan apa yang akan terjadi (hipotesis) dan kemudian mencari bukti yang mendukung. Analisa sistem dengan pembuatan tabel premis gejala penyakit ginjal, basis data, dan proses interface engine. Fitur-fitur yang disediakan yaitu halaman menu login yang diarahkan ke halaman menu master user, halaman admin akan diarahkan ke menu master gejala dan menu master penyakit.

Penelitian oleh [4] mengemukakan kemajuan teknologi, mendorong manusia untuk lebih memanfaatkan teknologi dalam berbagai kegiatan yang dilakukan terutama teknologi yang berhubungan dengan pengetahuan dan sistem pakar merupakan bagian dari teknologi yang berbasis pengetahuan. Petani sangat membutuhkan peran seorang pakar dalam mendiagnosa hama dan penyakit tanaman kacang tanah di Kabupaten Cianjur. Sayangnya, penjelasan metode backward chaining dalam sistem kurang diulas dan menimbulkan kurangnya pengetahuan dalam metode yang digunakan. Fitur-fitur yang disediakan yaitu halaman index yang diarahkan ke form menu utama; halaman login admin yang digunakan admin untuk menambahkan data di form data gejala, form data hama/penyakit, form kaidah produksi yang digunakan untuk menambahkan rule; form ubah sandi; form penanganan masalah; form data 
pengguna; form login pengguna untuk user yang diarahkan ke form konsultasi dimana diform konsultasi terdapat form hasil konsultasi; form cetak yang digunakan untuk mencetak hasil konsultasi yang dilakukan oleh pengguna; dan form panduan agar pengguna mengetahui cara kerja sistem.

Sedangkan menurut [5] mengemukakan perkembangan zaman yang semakin maju, dimana komputer dapat membantu mengerjakan pekerjaan manusia sehari-hari, komputer juga bisa menggantikan seorang pakar untuk mendiagnosa suatu penyakit apabila seorang pakar tersebut sedang tidak berada ditempat, pindah tugas, pensiun, atau pakar tersebut sudah meninggal dunia. Oleh karena itu dibangun suatu sistem pakar yang dapat membantu para pakar dalam menangani masalah diagnosa penyakit leukemia menggunakan metode inferensi Backward Chaining di RSUD Dr. M.Zein Painan Kabupaten Pesisir Selatan Sumatera Barat. Pada sistem pakar yang mendiagnosa penyakit leukemia, dengan pembuatan sebuah basis pengetahuan. Pengetahuannya yang berasal dari pakar tersebut dipresentasikan ke dalam bentuk-bentuk satuan pengetahuan. Proses inferensi yang digunakan pada deteksi kerusakan pada sistem kemudi adalah pelacakan mundur (Backward Chaining). Fitur-Fitur yang disediakan yaitu halaman index untuk user yang kemudian diarahkan ke form diagnosa penyakit Leukemia, halaman login pakar yang diarahkan untuk mengakses form input data penyakit, form input data gejala.

\section{METODE PENELITIAN}

Metode penelitian yang digunakan pada Sistem Diagnosa Penyakit Tanaman Cabai Merah dengan Metode Backward Chaining berupa studi pustaka, perancangan sistem dan basis data, implementasi, dan pengujian perangkat lunak sebagai berikut:

Studi Pustaka, Pada tahap ini dilakukan pengumpulan data dengan cara membaca dan memahami buku-buku referensi, dan media lain serta seorang pakar yang berkaitan dengan perangkat lunak yang akan dikembangkan.

Perancangan Sistem dan Basis Data, Pada tahap ini dilanjutkan dengan pembuatan proses bisnis, kebutuhan fungsional, perancangan database sistem hingga perancangan desain interface pada sistem pakar yang akan dibuat. Data-data penunjang, fakta-fakta dan aturan yang mengatur proses pencarian data yang saling berhubungan disimpan ke dalam basis data MySQL sebagai media penyimpanan.

Implementasi, Pada tahap ini dilakukan pembuatan sistem diagnosa penyakit pada tanaman cabai merah besar berdasarkan hasil perancangan yang telah dilakukan. Sistem ini menggunakan bahasa pemrograman PHP dan MySQL sebagai database.

Pengujian Perangkat Lunak, Pada tahap ini dilakukan uji coba terhadap sistem. Uji coba ini menggunakan black box testing yaitu terfokus pada sistem memenuhi kebutuhan (requirement) yang disebutkan dalam spesifikasi. Cara pengujian dilakukan dengan mengeksekusi sistem kemudian diamati apakah hasil dari sistem sesuai dengan proses bisnis dan spesifikasi. Apabila dalam uji coba ini masih terdapat kesalahan maka akan dilakukan evaluasi sehingga sistem dapat berjalan sesuai dengan yang diharapkan.

\section{HASIL DAN PEMBAHASAN}

Terdapat dua bagian penting dari sistem pakar yaitu lingkungan pengembangan dan lingkungan konsultasi. lingkungan pengembangan digunakan oleh pembuat sistem pakar atau admin untuk membangun komponenkomponennya dan memperkenalkan pengetahuan ke dalam knowledge base. Sedangkan lingkungan konsultasi digunakan oleh pengguna atau user untuk konsultasi sehingga pengguna mendapatkan pengetahuan dan solusi dari sistem pakar layaknya berkonsultasi dengan seorang pakar. Pembuatan sistem pakar ini mendasarkan tiap-tiap aturan yang di buat berdasarkan pohon keputusan. Untuk lebih jelasnya dapat dilihat pada Gambar 1. 


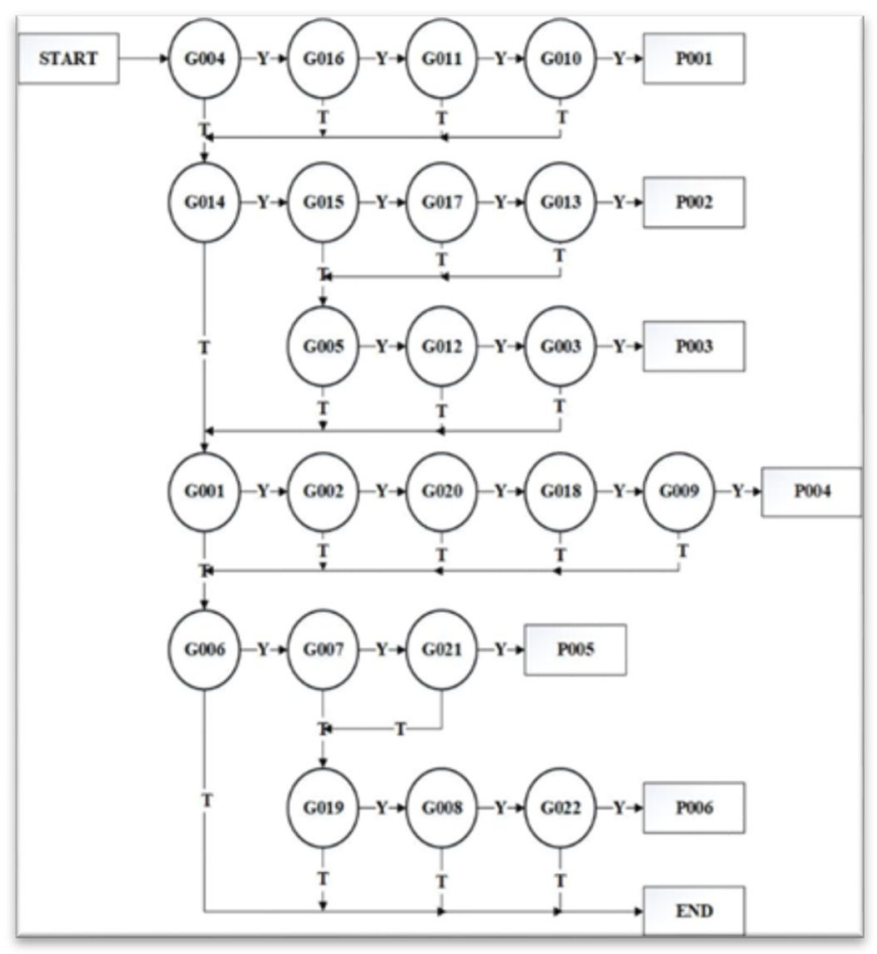

Gambar 1. Pohon Keputusan

Berdasarkan aturan if-then-else pada pohon keputusan yang telah dibuat, kemudian didapati rule dalam bentuk tabel seperti Tabel 1 berikut:

Tabel 1. Tabel Rule

\begin{tabular}{cl}
\hline Rule & Kondisi \\
\hline \multirow{3}{*}{1} & IF buah bercak mengkilap \\
& AND buah berair \\
& AND buah berubah warna \\
& AND luka melebar \\
& THEN busuk buah antraknosa \\
\hline \multirow{3}{*}{2} & IFtulang daun menguning \\
& AND daun berubah warna \\
& AND daun rontok \\
& AND buah kecil \\
& THEN virus mozaik \\
\hline & IF daun rontok \\
& AND batang rusak \\
& AND akar rusak \\
& AND daun coklat \\
& THEN bercak daun \\
& IF daun menguning \\
& AND tulang daun menebal \\
& AND daun keriting \\
& AND tanaman kerdil \\
& AND tidak berbuah \\
& THEN virus kuning \\
\hline & IF daun layu \\
& AND batang menguning tidak berlendir \\
\hline \multirow{2}{*}{5}
\end{tabular}




\begin{tabular}{ll}
\hline & AND akar coklat \\
& THEN layu fusarium \\
\hline & IF daun layu \\
& AND batang kecoklatan \\
6 & AND buah busuk \\
& AND batang berlendir \\
& THEN layu rolstonia \\
\hline
\end{tabular}

Berdasarkan aturan-aturan yang telah dibuat, untuk memudahkan dalam menganalisa maka datanya di buat dalam bentuk pada Table 2 .

Tabel 2. Tabel Keputusan

\begin{tabular}{cll}
\hline $\boldsymbol{R} U$ LE & $\boldsymbol{I F}$ & THEN \\
\hline 1 & $\mathrm{G} 004, \mathrm{G} 016, \mathrm{G} 011, \mathrm{G} 010$ & $\mathrm{P} 001$ \\
\hline 2 & $\mathrm{G} 014, \mathrm{G} 015, \mathrm{G} 017, \mathrm{G} 013$ & $\mathrm{P} 002$ \\
\hline 3 & $\mathrm{G} 014, \mathrm{G} 005, \mathrm{G} 012, \mathrm{G} 003$ & $\mathrm{P} 003$ \\
\hline 4 & $\mathrm{G} 001, \mathrm{G} 002, \mathrm{G} 020, \mathrm{G} 018, \mathrm{G} 009$ & $\mathrm{P} 004$ \\
\hline 5 & $\mathrm{G} 006, \mathrm{G} 007, \mathrm{G} 021$ & $\mathrm{P} 005$ \\
\hline 6 & $\mathrm{G} 006, \mathrm{G} 019, \mathrm{G} 008, \mathrm{G} 022$ & $\mathrm{P} 006$
\end{tabular}

Untuk penjelasan dari kode gejala pada penyakit dalam sistem dapat dilihat pada Tabel 3.

Tabel 3. Data Gejala

\begin{tabular}{ll}
\hline Kode & Ciri-Ciri \\
\hline G001 & Daun menguning \\
\hline G002 & Tulang daun menebal \\
\hline G003 & Daun coklat \\
\hline G005 & Buah bercak mengkilap \\
\hline G006 & Daun layu rusak \\
\hline G007 & Batang menguning tidak berlendir \\
\hline G008 & Buah busuk \\
\hline G009 & Tidak berbuah \\
\hline G010 & Luka melebar \\
\hline G011 & Buah berubah warna \\
\hline G012 & Akar rusak \\
\hline G013 & Buah mengecil \\
\hline G014 & Daun rontok \\
\hline G015 & Daun berubah warna \\
\hline G016 & Buah berair \\
\hline G017 & Tulang daun menguning \\
\hline G018 & Tanaman mengerdil \\
\hline
\end{tabular}




\begin{tabular}{ll}
\hline G019 & Batang kecoklatan \\
\hline G020 & Daun keriting \\
\hline G021 & Akar coklat \\
\hline G022 & Batang berlendir \\
\hline
\end{tabular}

Untuk penjelasan dari kode penyakit dan solusi atau knowledge base dalam sistem yang dibuat dapat dilihat pada Tabel 4.

Tabel 4. Knowladge base

\begin{tabular}{lll}
\hline Penyakit & Gejala \\
\hline P001 Penyakit Busuk Buah Antraknosa & G004 & Buah bercak mengkilap \\
& G016 & Buah berair \\
& G011 & Buah berubah warna \\
& G010 & Luka melebar \\
& & \\
\hline P002 Penyakit Virus Mozaik & G014 & Daun rontok \\
& G015 & Daun berubah warna \\
& G017 & Tulang daun menguning \\
& G013 & Buah mengecil \\
& & \\
\hline P003 Penyakit Bercak Daun & G014 & Daun rontok \\
& G005 & Batang rusak \\
& G012 & Akar rusak \\
& G003 & Daun coklat \\
& & \\
\hline P004 Penyakit Virus Kuning & G001 & Daun menguning \\
& G002 & Tulang daun menebal \\
& G020 & Daun keriting \\
& G018 & Tanaman mengerdil \\
& G009 & Tidak berbuah \\
& G006 & Daun layu \\
& G007 & Batang menguning tidak \\
& berlendir \\
& G021 & Akar coklat \\
\hline P005 Penyakit Layu Fusarium & G006 & Daun layu \\
& G008 & Batang kecoklatan busuk \\
& G022 & Batang berlendir \\
\hline P006 Penyakit Layu Rolstonia &
\end{tabular}

\subsection{Backward Chaining}

Backward chaining merupakan metode yang digunakan untuk menalarkan fakta-fakta dari pengujian hipotesis untuk mencari kebenaran. Backward chaining merupakan sebuah metode inferensi yang bekerja mundur kearah kondisi awal (Goal) kemudian mencari kecocokan fakta-fakta dengan premis-premis yang sudah dibuat (IF). Jika cocok, rule dieksekusi dan hipotesis ( THEM) ditempatkan dibasis data sebagai fakta baru. Sebaliknya, jika tidak cocok, premis akan disimpan sebagai sub Goal dan berakhir apabila Goal sudah ditemukan atau tidak ada rule yang membuktikan kebenaran dari Goal tersebut, alur backward chaining dapat dilihat pada Gambar 2. 


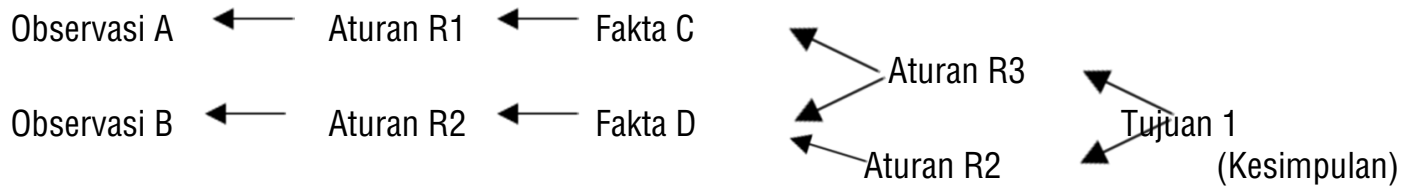

Gambar 2. Alur Backward Chaining [6]

\subsection{Tampilan Sistem}

Pada bagian ini menunjukkan bagaimana tampilan dari sistem meliputi bagian Home dari sistem hingga hasil output permasalahan dari Analisa penyakit pada tanaman cabai merah. Berikut tampilan utama program sistem pakar atau bisa disebut sebagai tampilan utama seorang user masuk dalam sistem dapat di lihat pada Gambar 3.

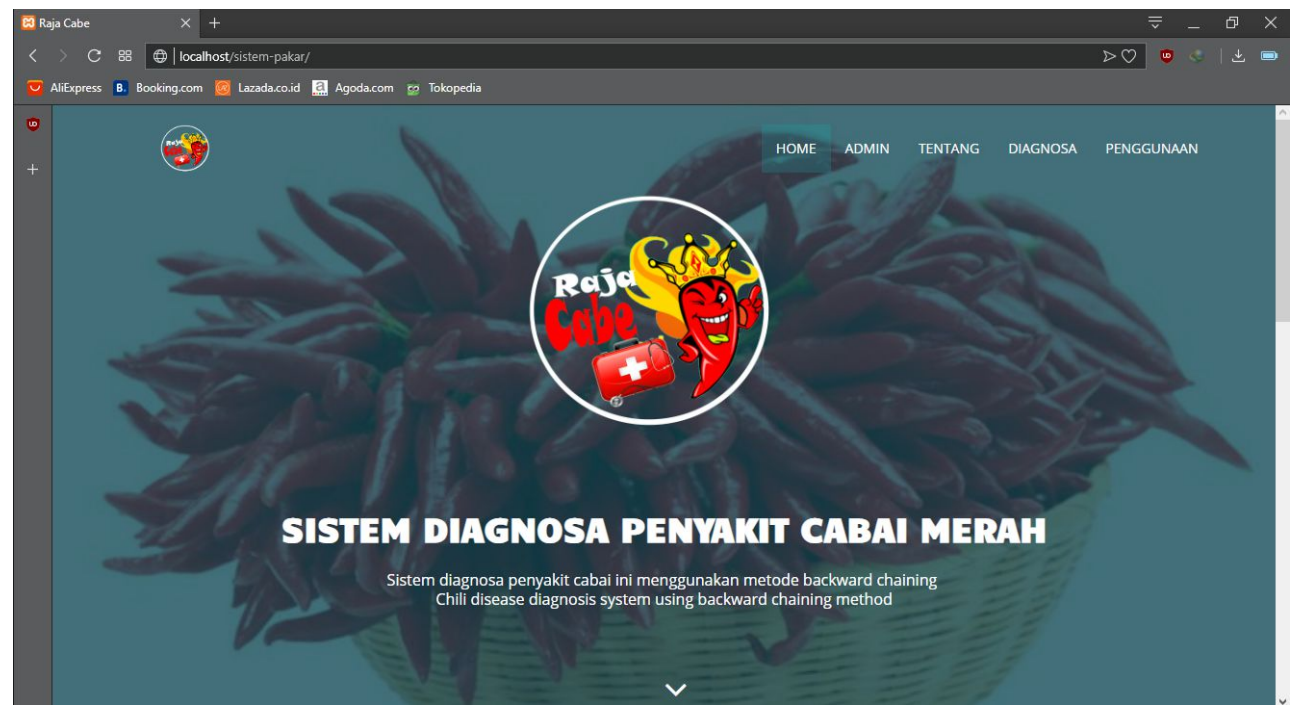

\section{Gambar 3. Tampilan Home}

Ketika menu diagnose di pilih maka tampilan diagnosa berupa daftar pertanyaan yang harus dijawab oleh user untuk menentukan penyakit pada taman cabai merah. User cukup memilih satu penyakit diantara penyakit yang ada untuk membuktikan kebenaran penyakit yang diduga seperti pada Gambar 4.

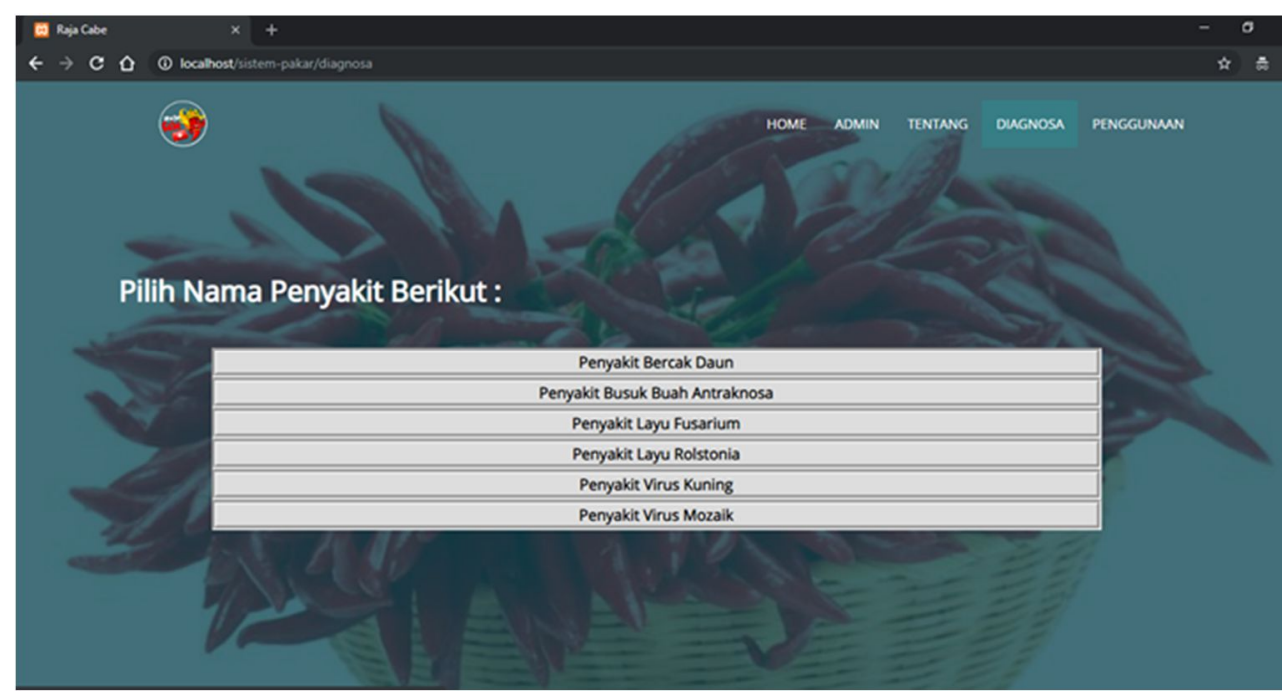

Gambar 4. Tampilan Diagnosa 
Setelah penyakit yang diduga dipilih seperti pada Gambar 4 akan disajikan beberapa pertanyaan yang berkaitan dengan penyakit tersebut hasil inilah yang membuktikan kebenaran penyakit yang dialami oleh tanaman cabai apabila dinilai benar maka akan menampilkan solusi untuk menangani penyakit tersebut jika tidak benar maka akan diarahkanberikut tampilan hasil analisa sistem berdasarkan analisa penyakit seperti pada Gambar 5.

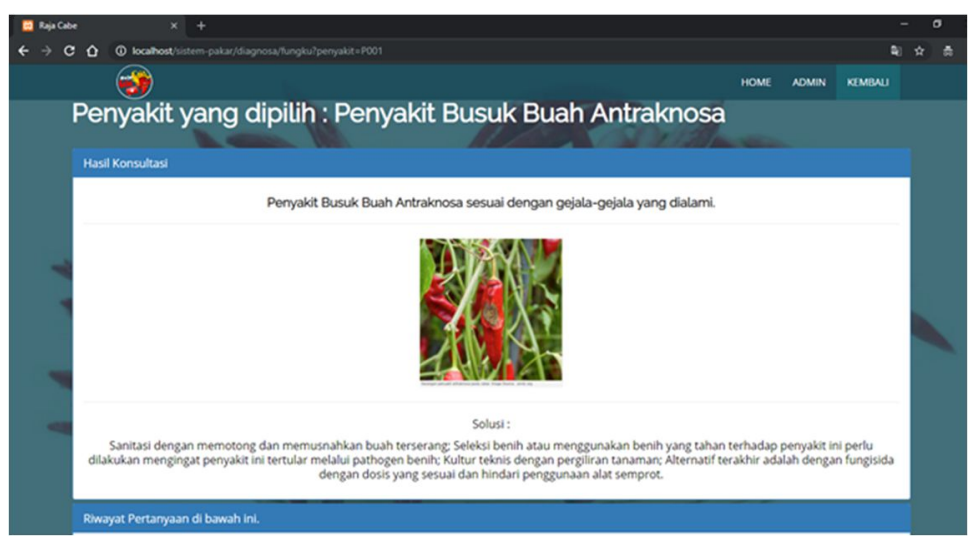

Gambar 5. Tampilan Hasil Analisa

\subsection{Pengujian Sistem}

Pengujian Sistem Diagnosa Penyakit pada Tanaman Cabai Merah dengan Metode Backward Chaining (Studi Kasus : Petani Cabai Merah Desa Grobongan Kabupaten Madiun) menggunakan blackbox testing dapat dilihat pada Tabel 5.

Tabel 5. Tabel Pengujian

\begin{tabular}{|c|c|c|c|c|}
\hline No. & Kasus/ Form yang diuji & Skenario Sistem & $\begin{array}{ll}\text { Hasil } & \text { yang } \\
\text { Diharapkan } & \\
\end{array}$ & $\begin{array}{l}\text { Hasil } \\
\text { Pengujian }\end{array}$ \\
\hline 1 & Login admin & $\begin{array}{lr}\text { Admin } & \text { login } \\
\text { menggunakan } & \\
\text { username } & \text { dan } \\
\text { password yang } & \text { sudah } \\
\text { ditentukan } & \end{array}$ & $\begin{array}{l}\text { Admin dapat login ke } \\
\text { halaman admin }\end{array}$ & Berhasil \\
\hline 2 & List data gejala & $\begin{array}{lr}\text { Admin memilih } & \text { menu } \\
\text { gejala } & \text { untuk } \\
\text { menampilkan } & \text { semua } \\
\text { data gejala } & \\
\end{array}$ & $\begin{array}{lr}\text { Admin } & \text { dapat } \\
\text { mengetahui list } & \text { gejala } \\
\text { yang } & \text { sudah } \\
\text { diinputkan } & \\
\end{array}$ & Berhasil \\
\hline 3 & Update data gejala & $\begin{array}{l}\text { Admin memilih button } \\
\text { update salah satu data } \\
\text { gejala }\end{array}$ & $\begin{array}{l}\text { Admin dapat } \\
\text { melakukan update dan } \\
\text { tersimpan ke database }\end{array}$ & Berhasil \\
\hline 4 & Delete data gejala & $\begin{array}{l}\text { Admin memilih button } \\
\text { delete salah satu data } \\
\text { gejala }\end{array}$ & $\begin{array}{l}\text { Data terhapus baik } \\
\text { disistem maupun } \\
\text { database }\end{array}$ & Berhasil \\
\hline 5 & Input data gejala & $\begin{array}{l}\text { Admin memilih menu } \\
\text { create pada menu gejala }\end{array}$ & $\begin{array}{l}\text { Admin dapat input } \\
\text { data gejala melalui } \\
\text { sistem dan tersimpan } \\
\text { di database }\end{array}$ & Berhasil \\
\hline 6 & List data penyakit & $\begin{array}{lr}\text { Admin memilih } & \text { menu } \\
\text { penyakit } & \text { untuk } \\
\text { menampilkan } & \text { semua } \\
\text { data penyakit } & \\
\end{array}$ & $\begin{array}{lr}\text { Admin } & \text { dapat } \\
\text { mengetahui } & \text { list } \\
\text { penyakit yang } & \text { sudah } \\
\text { diinputkan } & \\
\end{array}$ & Berhasil \\
\hline 7 & Update data penyakit & $\begin{array}{l}\text { Admin memilih button } \\
\text { update salah satu data } \\
\text { penyakit }\end{array}$ & $\begin{array}{l}\text { Admin dapat } \\
\text { melakukan update dan } \\
\text { tersimpan ke database }\end{array}$ & Berhasil \\
\hline
\end{tabular}




\begin{tabular}{|c|c|c|c|c|}
\hline 8 & Delete data penyakit & $\begin{array}{l}\text { Admin memilih } \text { button } \\
\text { delete salah satu } \\
\text { penyakit }\end{array}$ & $\begin{array}{l}\text { Data terhapus baik } \\
\text { sistem atau database }\end{array}$ & Berhasil \\
\hline 9 & Input data penyakit & $\begin{array}{l}\text { Admin memilih menu } \\
\text { create pada halaman } \\
\text { penyakit }\end{array}$ & $\begin{array}{l}\text { Admin dapat input } \\
\text { data penyakit melalui } \\
\text { sistem dan tersimpan } \\
\text { di database }\end{array}$ & Berhasil \\
\hline 10 & List data rule & $\begin{array}{lr}\text { Admin memilih } & \text { menu } \\
\text { rule } & \text { untuk } \\
\text { menampilkan } & \text { semua } \\
\text { data rule } & \end{array}$ & $\begin{array}{l}\text { Admin dapat } \\
\text { mengetahui list rule } \\
\text { yang sudah ada }\end{array}$ & Berhasil \\
\hline 11 & Update data rule & $\begin{array}{l}\text { Admin memilih button } \\
\text { update salah satu data } \\
\text { rule }\end{array}$ & $\begin{array}{l}\text { Admin dapat } \\
\text { melakukan update dan } \\
\text { tersimpan ke database }\end{array}$ & Berhasil \\
\hline 12 & Delete data rule & $\begin{array}{l}\text { Admin memilih button } \\
\text { delete salah satu data } \\
\text { rule }\end{array}$ & $\begin{array}{l}\text { Data terhapus baik } \\
\text { sistem atau database }\end{array}$ & Berhasil \\
\hline 13 & Input data rule & $\begin{array}{l}\text { Admin memilih menu } \\
\text { create pada halaman } \\
\text { rule }\end{array}$ & $\begin{array}{lr}\text { Admin } & \text { dapat } \\
\text { menambahkan data } \\
\text { rule melalui sistem } \\
\text { dan tersimpan di } \\
\text { database }\end{array}$ & Berhasil \\
\hline 14 & Pilih penyakit & $\begin{array}{l}\text { User memilih menu } \\
\text { diagnosa dan memilih } \\
\text { sebuah penyakit }\end{array}$ & $\begin{array}{l}\text { User dapat memilih } \\
\text { penyakit untuk } \\
\text { mengetahui gejala dan } \\
\text { solusinya }\end{array}$ & Berhasil \\
\hline 15 & Jawab Pertanyaan & $\begin{array}{lr}\text { User } & \text { menjawab } \\
\text { pertanyaan } & \text { yang } \\
\text { diajukan oleh } & \text { sistem }\end{array}$ & $\begin{array}{l}\text { User dapat memilih } \\
\text { opsi yes atau no dan } \\
\text { menampilkan riwayat } \\
\text { pertanyaan }\end{array}$ & Berhasil \\
\hline 15 & Hasil Diagnosa & $\begin{array}{lr}\text { User mengetahui hasil } \\
\text { setelah menjawab } \\
\text { pertanyaan yang } \\
\text { diajukan oleh sistem }\end{array}$ & $\begin{array}{l}\text { User mengetahui hasil } \\
\text { dan solusinya }\end{array}$ & $\begin{array}{l}\text { Berhasil } \\
\text { (dapat dilihat } \\
\text { pada gambar } \\
\text { 5) }\end{array}$ \\
\hline
\end{tabular}

\section{KESIMPULAN}

Penelitian sistem pakar telah dilakukan dan menghasilkan kesimpulan bahwa dalam pembuatan Sistem Diagnosa Penyakit pada Tanaman Cabai Merah dengan Metode Backward Chaining (Studi Kasus : Petani Cabai Merah Desa Grobongan Kabupaten Madiun) dibagun sebuah sistem pakar yang mampu mendiagnosa penyakit pada tanaman cabai merah dengan metode backward chaining. Aplikasi ini dapat membantu pengguna khususnya petani cabai merah dalam memberikan solusi terhadap penyakit pada tanaman cabai merah berdasarkan gejala yang dialami. Dibandingkan sistem pakar lain penggunaan metode dalam sistem ini merupakan metode yang menentukan kebenaran dari dugaan penyakit yang sudah diketahui sedangkan sistem pakar lain menggunakan metode untuk mencari hasil dari gejala dimana penyakitnya belum diketahui. Maka, sistem ini sangat berguna untuk petani di Desa Grobongan dimana petani sudah mengetahui penyakit tapi tidak tahu kebenaran penyakit tersebut sesuai dengan pakar dalam sistem pakar.

Sistem pakar ini masih dapat dikembangkan dengan penambahan basis data yang masih tergolong pada penyakit cabai merah; sistem ini belum diaplikasikan dengan metode Certainty Factor dimana metode ini digunakan untuk menentukan tingkat kepercayaan melalui kondisi yang sedang dihadapi, namun sistem ini pengguna hanya diberikan pilihan yang mengakibatkan pengguna hanya memperoleh jawaban yang mutlak bukan berupa pendekatan; Sistem ini hanya menampilkan nama penyakit yang sesuai dengan pendekatan gejala dilapangan, apabila untuk memastikan kebenarannya perlu dilakukan penelitian. 


\section{DAFTAR PUSTAKA}

[1] R. H. Minarni, "Rancang Bangun Aplikasi Sistem Pakar Untuk Kerusakan Komputer Dengan Metode Backward Chaining," Jurnal TEKNOIF, Vol.1, No.1, pp. 26-35, 2013.

[2] F. A. Tarigan, "Sistem Pakar Untuk Mendiagnosa Penyakit Ginjal dengan Metode Backward Chaining," Jurnal TIMES, vol. 3, no. 2, pp. 25-29, 2014.

[3] B. A. A. Maulina and H. D. S, "Sistem Pakar Diagnosis Hama dan Penyakit Tanaman Kacang Tanah Berbasis Desktop Dengan Metode Backward Chaining," Media Jurnal Informatika, vol. 8, no. 1, pp. 25-32, 2016.

[4] Nofriadiman, E. Wati and R. F. Yeni, "Sistem Pakar Untuk Mendiagnosa Penyakit Leukemia Dengan Metode Backward Chaining," Jurnal Sains Dan Teknologi STTIND Padang, vol. 16, no. 2, pp. 1-10, 2016.

[5] Z. Azmi and Y. Verdi, Pengantar Sistem Pakar dan Metode, Jakarta: Mitra Wacana Media, 2017.

[6] S. Nuraisah, I. Wijaya and M. Astiningrum, "Sistem Pakar Mendiagnosa Penyakit Kusta Menggunakan Metode Backward Chaining," Jurnal Informatika POLINEMA, vol. 1, no. 4, pp. 55-60, 2015. 